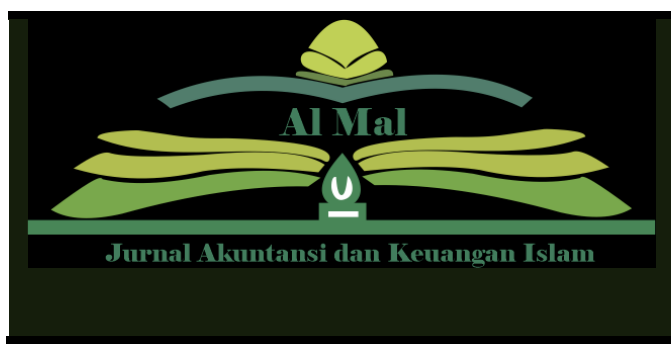

Al-Mal: JurnalAkuntansi dan Keuangan Islam E-ISSN: 2715-9477, P-ISSN: 2751-954X

Volume 02 Issue 02, 21 Juli 2021

Journal Page is available to:

http://ejournal.radenintan.ac.id/index.php/al-mal/index

\title{
Analisa Pengaruh Struktur Modal, Premi Netto dan Profitabilitas terhadap Solvabilitas Perusaaan Asuransi di Indonesia
}

\author{
Fauzan Akbar Albastiah ${ }^{1 *}$, Fauzi Isnaen ${ }^{2}$
}

${ }_{1,2 *}$ Departement of Economics, Faculty of Economics and Business Universitas Bina Sarana Informatika, Indonesia

\begin{tabular}{l}
\hline \multicolumn{1}{c}{ ARTICLE INFO } \\
\hline Article history: \\
Received 05-07-2021 \\
Revised 07-07-2021 \\
Accepted 07-07-2021 \\
Available 21-07-2021 \\
Revised (1) 23-07-2022 \\
Accepted 30-07-2022 \\
Revised Available 31-07-2022 \\
\hline Kata Kunci: Modal, Premi Neto, \\
Struktur Mrofitabilitas, Solvabilitas \\
Pros
\end{tabular}

Paper type: Research paper

Please cite this article: Albastiah, F. A., \& Isnaen, F. "Analisa Pengaruh Struktur Modal, Premi Netto dan Profitabilitas terhadap Solvabilitas Perusaaan Asuransi di Indonesia" Al-Mal: Jurnal Akuntansi dan Keuangan Islam [ONLINE], Volume 02 Number 02 (Juli 21, 2021)

Cite this document:

Al-Mal 2th edition

*Corresponding author

e-mail: fauzan.fab@bsi.ac.id

\begin{tabular}{l}
\hline ABSTRAK \\
\hline Penelitian ini bertujuan untuk menganalisis \\
pengaruh struktur modal, premi netto dan \\
profitabilitas terhadap solvabilitas perusahaan \\
asuransi di Indonesia. Metode pendekatan pada \\
penelitian ini menggunkan pendekatan kuantitatif \\
deskriptif. Obyek penelitian ini adalah perusahaan \\
asuransi di Indonesia data penelitian berasal dari \\
laporan keuangan Perusahaan Asuransi di \\
Indonesia tahun 2014-2018. Alat olah data yang \\
digunakan untuk menguji data sampel penelitian \\
yaitu eviews sebagai alat bantu untuk menganalisis \\
data. Hasil penelitian menunjukkan bahwa struktur \\
modal, premi netto dan profitabilitas tidak \\
mempunyai pengaruh terhadap solvabilitas \\
perusahaan asuransi di Indonesia. Keterbatasan \\
penelitian ini yaitu hanya membahas seberapa \\
besar pengaruh struktur modal, premi netto dan \\
profitabilitas berpengaruh positif signifikan \\
terhadap solvabilitas perusahaan asuransi di \\
Indonesia, selain itu jumlah sampel dan populasi \\
yang diteliti hanya perusahaan asuransi di \\
Indonesia sehingga membuka peluang untuk \\
peneliti-peneliti yang baru dengan mengangkat \\
tema yang sama dengan jumlah sampel objek \\
penelitian yang lebih banyak. Implikasi penelitian \\
ini diharapkan agar bisa menambah khasanah ilmu \\
pengetahuan berkaitan dengan pengaruh struktur \\
modal, premi netto dan profitabilitas berpengaruh \\
positif signifikan terhadap solvabilitas perusahaan \\
asuransi di Indonesia. \\
\hline Al-Mal with CC BY license. Copyright $\odot 2021$ the author(s) \\
\hline
\end{tabular}




\begin{abstract}
This study aims to analyze the effect of capital structure, net premium and profitability on the solvency of insurance companies in Indonesia. The approach method in this study uses a descriptive quantitative approach. The object of this research is insurance companies in Indonesia. The research data comes from the financial statements of insurance companies in Indonesia in 2014-2018. The data processing tool used to test the research sample data is eviews as a tool to analyze the data. The results showed that capital structure, net premium and profitability had no effect on the solvency of insurance companies in Indonesia. The limitation of this study is that it only discusses how much influence capital structure, net premium and profitability have a significant positive effect on the solvency of insurance companies in Indonesia, in addition to the number of samples and population studied only insurance companies in Indonesia, thus opening up opportunities for new researchers by raising the same theme with a larger number of samples of research objects. The implication of this research is that it is expected to be able to add to the repertoire of knowledge related to the effect of capital structure, net premiums and profitability have a significant positive effect on the solvency of insurance companies in Indonesia.
\end{abstract}

\title{
Keywords : Capital Structure, Net Premium, Profitability, Solvency
}

\section{PENDAHULUAN}

Perusahan Asuransi merupakan salah satu lembaga keuangan non bank yang bergerak dalam bidang layanan jasa dan bidang perasuransian yang membantu masyarakat mengatasi resiko yang terjadi dengan cara seseorang mengikatkan diri kepada perusahaan, untuk mendapatkan perlindungan dimasa yang akan datang, yang mana kekuatan dari perusahaan asuransi terletak pada peningkatan aset perusahaan, pelayanan, jumlah nasabah, dan jumlah pendapatan premi yang dihimpun dari nasabah. Industri asuransi di Indonesia semakin berkembang dari tahun ke tahun dan kesadaran akan pentingnya proteksi serta investasi menarik minat masyarakat untuk membeli premi asuransi. Asuransi juga dapat menjadi salah satu alternatif bagi masyarakat dalam pemilihan investasi dimana terdapat dua unsur yang ditawarkan oleh asuransi yaitu unsur proteksi sebagai unsur utama dan investasi sebagai unsur tambahan.

Menurut Otoritas Jasa Keuangan jumlah pemlik asuransi di Indonesia tidak lebih dari $2 \%$ dari total jumlah penduduk yang sekitar 250 juta jiwa, jadi 
potensi untuk terus tumbuhnya asuransi di Indonesia sangat besar. Semakin berkembangnya suatu industri asuransi maka pemerintah harus melakukan pengawasan yang ketat terhadap industri asuransi tersebut. Memberikan kenyamanan terhadap masyarakat atas setiap dana yang di investasikan pada perusahaan asuransi merupakan tanggung jawab pemerintah juga.

Pada tahun 2014, Otoritas Jasa Keuangan membuat pernyataan ada lima perusahaan asuransi yang tidak mampu memenuhi persyaratan modal minimum atau insolvent, dimana tiga perusahaan asuransi jiwa dan dua perusahaan asuransi umum. Pada akhir tahun 2014 berdasarkan data dari Asosiasi Asuransi Jiwa Indonesia (AAJI) terdapat setidaknya 10 perusahaan yang tidak memenuhi standar ratio solvabilitas dari 55 perusahaan asuransi jiwa. Regulator melakukan pengawasan ketat jika perusahaan asuransi tidak mampu melakukan pengelolaan usahanya dengan baik maka regulator akan mencabut ijin usaha perasuransiannya salah satu contoh pada tahun 2013 Otoritas Jasa keuangan menutup Asuransi Bumi Asih Jasa. Dengan adanya fenomena tersebut mendorong perusahaan asuransi di Indonesia agar mampu meningkatkan nilai solvabilitasnya dengan pengelolaan usahanya yang baik.

Perusahaan asuransi yang mengalami keadaan insolvency dengan memiliki nilai RBC lebih rendah cenderung terindikasi akan mengalami kebangkrutan dibandingkan perusahaan asuransi yang memiliki nilai RBC yang tinggi. Oleh karena itu, nilai RBC memberikan informasi tentang kekuatan keuangan perusahaan asuransi di dalam melakukan operasi usahanya.

Peneliti akan mengambil beberapa perusahaan asuransi di Indonesia dan terdapat komponen keuangan yang digunakan dalam melakukan penilaian solvabilitas perusahaan asuransi di antaranya total investasi, total ekuitas, total kewajiban, premi, pendapatan, beban, dan laba sebelum pajak. Penelitian ini akan dapat menyimpulkan apakah struktur modal, premi neto dan profitabilitas mempengaruhi tingkat solvabilitas perusahaan asuransi.

Menurut Haan dan Kakes (2010), menyebutkan ada 7 variabel yang berhubungan dengan solvabilitas sebuah perusahaan asuransi di antaranya 
ukuran perusahaan, profitabilitas, reasuransi, risiko underwriting, lini bisnis, herfindahl dan proporsi saham. Penelitian tersebut menyimpulkan bahwa ukuran perusahaan, profitabilitas berkontribusi dalam solvabilitas perusahaan asuransi yang tinggi. Sedangkan risiko underwriting, lini bisnis, herfindahl, dan reasuransi tidak secara signifikan berkontribusi dalam solvabilitas perusahaan asuransi.

Struktur modal sangat penting bagi industri asuransi karena pendanaan permanen yang terdiri dari utang jangka panjang, saham preferen dan modal pemegang saham. Komposisi dari sumber-sumber pembiayaan yang digunakan perusahaan dalam bentuk persamaan, maka hubungan antara struktur keuangan dan struktur modal adalah struktur keuangan dikurangi utang jangka pendek akan sama dengan struktur modal. Penelitian yang dilakukan oleh Nasrullahi M Tanjung (2015) atas penggunaan struktur modal dalam kaitannya dengan solvabilitas menunjukan penurunan struktur modal akan meningkatkan rasio solvabilitas jika peningkatan modal sendiri dibarengi dengan penurunan penggunaan hutang jangka panjang dan peningkatan penggunaan hutang jangka panjang yang lebih besar dibandingkan peningkatan penggunaan modal sendiri dapat meningkatkan rasio solvabilitas dalam peningkatan yang rendah, dengan kata lain struktur modal memiliki pengaruh yang signifikan.

\section{Agency Theory}

Teori keagenan mendasari praktek pengungkapan laporan tahunan oleh perusahaan terhadap para pemegang saham. Teori keagenen Jensen and Meckling (1976) memiliki asumsi bahwa para pemegang saham tidak memiliki cukup informasi tentang kinerja dan kondisi perusahaan. Agen memiliki lebih banyak informasi mengenai kapasitas diri, lingkungan kerja, dan prospek perusahaan secara keseluruhan dimasa yang akan datang dibandingkan dengan principal (Hidayat, 2017). Sedangkan menurut (Wahidahwati, 2005), teori keagenan menjelaskan bahwa perusahaan yang memisahkan fungsi kepemilikan akan rentan terhadap konflik keagenan. Penyebab konflik antara 
manajer dengan pemegang saham berkaitan dengan aktivitas pencarian dana dan bagaimana dana tersebut diinvestasikan.

Teori agensi mengasumsikan bahwa semua individu bertindak sesuai dengan kepentingannya masing-masing. Agen diasumsikan menerima kepuasan tidak hanya dari kompensasi finansial tetapi juga dari keuntungankeuntungan lain yang diperoleh dari hubungan agensi. Keuntungan tersebut dapat berupa waktu luang (leisure time), kondisi pekerjaan yang atraktif, fleksibilitas jam kerja, dan lain-lain. Dalam kondisi ini, agen dikatakan mempunyai sikap opportunistic (mementingkan dirinya sendiri) (Komalasari, 1999). Dalam teori ini perusahaan tidak menentukan target rasio hutang, karena ada dua jenis pendanaan internal yang preferensinya berbeda yang bisa dipilih perusahaan, yaitu laba ditahan sampai penerbitan saham baru. Rasio hutang perusahaan akan di-pengaruhi oleh kebutuhan perusahaan untuk melakukan investasi (Oktaviani, 2012).

Inilah yang menyebabkan adanya ketidakseimbangan informasi yang dimiliki antara prinsipal dan agen, sehingga mengakibatkan asimetri infomrasi. Munculnya masalah keagenan terjadi karena ada pihak-pihak yang memiliki perbedaan kepentingan pribadi namun saling bekerja sama dalam pembagian wewenang yang berbeda. Masalah keagenan ini dapat merugikan prinsipal karena pihak prinsipal tidak mendapatkan informasi yang memadai dan tidak memiliki cukup akses dalam mengelola perusahaan.

\section{Pecking order theory}

Pecking order theory diperkenalkan oleh Donaldson pada 1961 dan penamaan pecking order theory dilakukan oleh Myers pada 1984 (Riswan dan Sari, 2015). Perusahaan yang ingin berkembang selalu membutuhkan modal yang salah satunya diperoleh dari hutang. Namun demikian, perusahaan tidak mudah untuk memeroleh pinjaman karena harus menganalisis lebih dahulu apakah memang sudah tepat untuk berhutang. Jika sumber-sumber dari internal, seperti modal sendiri atau laba ditahan masih kurang, maka perusahaan dapat melakukan pinjaman. Untuk itu, perlu dianalisis untung 
ruginya melakukan pinjaman. Menurut Pudjiastuti dan Suad Husnan dalam Tunnisa (2016) Pecking Order Theory adalah urutan sumber pendanaan dari internal (laba ditahan) dan eksternal (penerbitan ekuitas baru). Teori ini menjelaskan keuputusan pendanaan yang diambil oleh perusahaan. Pecking Order Theory menjelaskan mengapa perusahaan-perusahaan yang Profitable umumnya meminjam dalam jumlah yang sedikit. Hal tersebut bukan disebabkan karena mempunyai target Debt Rasio yang rendah, tetapi karena memerlukan pendanaan dari luar yang sedikit.

Menurut (Mayangsari, 2001) menyatakan bahwa Teori ini menjelaskan mengenai pemilihan sumber pendanaan yang membandingkan antara sumber pendanaan internal dan eksternal, namun teori ini tidak menjelaskan mengenai kombinasi pendanaan perusahaan, melalui utang atau ekuitas. Pecking order theory menyatakan bahwa perusahaan dengan tingkat pertumbuhan yang cepat harus lebih banyak mengandalkan pada modal eksternal. Dengan demikian perusahaan dengan tingkat pertumbuhan yang tinggi cenderung lebih banyak menggunakan utang. Teori Pecking Order menunjukkan bahwa perusahaan lebih suka menggunakan laba ditahan untuk membayar dividen dan membiayai investasi baru. Teori Pecking Order memprediksi hubungan negatif antara rasio laba dan hutang, selain itu teori ini juga menunjukkan bahwa struktur modal perusahaan yang diamati memiliki hubungan positif dengan ukuran, pertumbuhan dan kekayaan atau aset perusahaan (Oktavina \& Manalu, 2018).

Pecking Order Theory juga menjelaskan mengenai terjadinya asimetri informasi atas penggunaan sumber dana eksternal antara manajemen perusahaan dan investor, dimana informasi yang lebih komprehensif mengenai kondisi perusahaan saat ini dan prospek masa depan perusahaan hanya dimiliki oleh salah satu pihak, yaitu manajemen perusahaan (Dewi Yanti \& Wirama, 2017). Pecking Order Theory mampu menjelaskan preferensi perusahaan dalam menentukan struktur modal optimal. Teori ini menyatakan bahwa terdapat tata urutan keputusan pendanaan perusahaan dalam 
menentukan struktur modal optimal, yaitu memilih sumber dana internal dan kemudian sumber dana eksternal, dengan urutan utang terlebih dahulu dan sekuritas ekuitas sebagai alternatif terakhir (Noor, 2015).

Perusahaan yang kurang Profitable akan cenderung mempunyai hutang yang lebih besar karena dua alasan, yaitu dana yang tidak cukup dan hutang merupakan sumber dana yang lebih disukai (Indriyani, 2017). Dana internal lebih disukai daripada dana eksternal karena dana internal memungkinkan perusahaan untuk tidak perlu membuka diri lagi dari sorotan luar. Kalau bisa memeroleh sumber dana yang diperlukan tanpa memeroleh sorotan dan publisitas publik sebagai akibat penerbitan saham baru. Sumber dana eksternal lebih disukai dalam bentuk hutang daripada modal sendiri karena dua alasan. Pertama adalah pertimbangan biaya emisi, biaya emisi obligasi akan lebih mudah dari biaya emisi saham baru. Hal ini disebabkan karena penerbitan saham baru akan menurunkan harga saham lama. Kedua, manajer khawatir kalau penerbitan saham baru akan ditafsirkan sebagai kabar jelek oleh pemodal dan membuat harga saham akan turun. Hal ini disebabkan antara lain oleh kemungkinan adanya informasi asimetris antara pihak manajemen dengan pihak pemodal (Pudjiastuti dan Suad Husnan dalam Tunnisa, 2016).

\section{Definisi Struktur Modal}

Struktur modal perusahaan merupakan salah satu faktor fundamental dalam operasi perusahaan. Struktur modal suatu perusahaan ditentukan oleh kebijakan pembelanjaan dari manajer keuangan yang senantiasa dihadapkan pada pertimbangan baik yang bersifat kualitatif maupun kuantitatif. (Utami Laksita, 2013) Irham Fahmi (2015:184) menyatakan bahwa struktur modal adalah sebagai berikut: "Struktur modal merupakan gambaran dari bentuk proporsi finansial perusahaan yaitu antara modal yang dimiliki yang bersumber dari utang jangka panjang (long-term liabilities) dan modal sendiri (shareholders' equity) yang menjadi sumber pembiayaan suatu perusahaan". Menurut Abdul Halim (2015:81) struktur modal adalah sebagai berikut: "Struktur modal merupakan perbandingan antara total hutang (modal asing) 
dengan total modal sendiri/ekuitas)". Menurut Agus Sartono (2012:225) struktur modal adalah sebagai berikut: "Struktur modal merupakan perimbangan jumlah utang jangka pendek yang bersifat permanen, utang jangka panjang, saham preferen dan saham biasa".

Struktur modal adalah bauran penggunaan dana yang berasal dari ekuitas dan hutang. Konsekuensi yang harus ditanggung perusahaan apabila menggunakan hutang adalah perusahaan harus menaati perjanjian hutang. Apabila perusahaan menggunakan sumber dana berupa penerbitan saham maka perusahaan harus memberikan imbalan kepada investor berupa dividen. Struktur modal dalam perusahaan berkaitan erat dengan investasi sehingga dalam hal ini akan menyangkut sumber dana yang digunakan untuk membiayai proyek investasi tersebut (Wikartika \& Fitriyah, 2018).

Berdasarkan pengertian tersebut dapat disimpulkan bahwa struktur modal adalah bagian dari struktur keuangan yang merupakan perbandingan antara utang jangka pendek yang bersifat permanen, utang jangka panjang, saham preferen dan saham biasa yang digunakan oleh perusahaan.

\section{Definisi Premi Netto}

Menurut PMK 53 tahun 2012 premi neto adalah premi bruto setelah dikurangi premi reasuransi, setelah premi reasuransi bayar dikurangi komisinya (premi retensi sendiri). Salah satu komponen pendapatan underwriting ( $U W$ Result) adalah premi neto. Berikut rumus Premi Neto merurut PER-09/Bl/2011:

Premi Neto $=$ Premi Bruto-Komisi-Premi Reasuransi

Makin besar pendapatan premi neto dan makin terkendali besarnya beban klaim neto akan menghasilkan surplus underwriting yang berarti menunjukkan keberhasilan perusahaan dalam mengelola risiko yang diterimanya dari tertanggung. Idealnya, perusahaan yang berhasil memperoleh premi neto dalam jumlah besar juga akan berhasil memperoleh laba yang besar pula. Namun sebenarnya oleh karena masih terdapat komponen lain dalam perhitungan laba rugi seperti tersebut di atas, tentunya laba rugi dipengaruhi 
juga secara langsung oleh komponen lain tersebut. Premi harus dibayar tepat waktu dan jumlahnya biasanya ditentukan oleh pihak penanggung. Apabila dalam perjanjian asuransi pihak tertanggung tidak dapat melaksanakan kewajibannya membayar premi lanjutannya tepat waktu atau pembayaran preminya terhenti sebelum masa pertanggungannya berakhir, maka pihak penanggung dapat membatalkan perjanjian asuransi (Tamalonggehe et al., 2017). Dalam mengevaluasi kinerja operasional suatu perusahaan asuransi, biasanya juga pendapatan premi neto juga akan dibandingkan dengan beban usaha, beban klaim dan pengeluaran komisi asuransi. Pengukuran ini penting untuk mengetahui apakah biaya-biaya yang dikeluarkan.

\section{Definisi Profitabilitas}

Menurut Niresh dan Velnampy (2014) "Profitabilitas adalah sejumlah uang perusahaan yang dapat dihasilkan dari sumberdaya apapun yang dimiliki perusahaan. Karena tujuan akhir dari setiap perusahaan adalah memaksimalkan profitabilitas". Pengertian profitabilitas menurut Sofyan Syafri Harahap (2009) menyatakan bahwa Profitabilitas menggambarkan kemampuan perusahaan mendapatkan laba melalui semua kemampuan dan sumber yang ada seperti kegiatan penjualan, kas, modal, jumlah karyawan, jumlah cabang dan sebagainya. Sedangkan menurut Agus Sartono Yeti Rohaeti (2003) menyatakan "profitabilitas adalah kemampuan perusahaan memperoleh laba dalam hubungannya dengan penjualan, total aktiva maupun modal sendiri".

Tingkat profitabilitas dapat menunjukkan kemampuan perusahaan untuk mendanai kegiatan operasionalnya sendiri. Selain itu, profitabilitas juga menunjukkan kemampuan perusahaan untuk membayar utang jangka panjang dan bunganya (Nelyumna, 2018). Secara garis besar ada 4 jenis rasio keuangan yang dapat digunakan untuk menilai kinerja suatu perusahaan, yaitu rasio likuiditas, rasio leverage, rasio aktivitas, dan rasio profitabilitas. Profitabilitas adalah hasil akhir dari sejumlah kebijakan dan keputusan yang dilakukan oleh perusahaan. Dari sudut pandang investor, salah satu indikator penting untuk 
menilai prospek perusahaan di masa datang adalah dengan melihat sejauh mana pertumbuhan profitabilitas perusahaan.

Rasio yang menunjukkan profitabilitas dalam kaitannya dengan penjualan yakni margin laba kotor (gross profit margin) dan marjin laba bersih (net profit margin). Sedangkan rasio yang menunjukkan profitabilitas dalam kaitannya dengan investasi yakni tingkat pengembalian atas aktiva (return on assets) dan tingkat pengembalian atas ekuitas (return on equity). Perusahaan asuransi yang memiliki tingkat profitabilitas tinggi dapat menjadi sumber pendanaan internal yang berguna untuk menopang di dalam pertanggungan atas risiko yang ditanggung.

\section{Definisi Solvabilitas}

Pengertian Solvabilitas menurut Sutrisno (2007) adalah kemampuan suatu entitas bisnis untuk memenuhi kewajiban keuangannya pada saat jatuh tempo. Solvabilitas menunjukkan kemampuan perusahaan untuk memenuhi segala kewajiban finansialnya apabila sekiranya perusahaan tersebut pada saat itu dilikuidasikan. Tingkat solvabilitas sebuah perusahaan tidak menggambarkan tingkat likuiditasnya, sebuah perusahaan yang solvable belum tentu likuid dan sebaliknya. Solvabilitas atau leverage mengukur sebatas mana total aktiva dibiayai oleh pemilik (Mahfud, 2015). Analisa solvabilitas berfokus pada kemampuan suatu perusahaan untuk memenuhi kewajiban jangka panjang dan jangka pendek. perusahaan yang tidak solvabel berarti perusahaan tersebut memiliki modal yang tidak mencukupi untuk melunasi hutangnya sehingga perusahaan tersebut akan mengalami kesulitan untuk memperoleh tambahan pinjaman dari kreditur sebelum perusahaan menambah modalnya sendiri. Keadaan ini menyebabkan perusahaan sulit untuk mengadakan perluasan dan peningkatan produksi.

Perusahaan yang mempunyai rasio hutang yang tinggi menghadapi resiko yang lebih tinggi pada masa resesi, tetapi tingkat pengembalian yang diharapkan perusahaan juga lebih tinggi pada masa cerah. Sebaliknya, perusahaan dengan rasio hutang yang rendah tidak beresiko besar, tetapi 
peluangnya untuk melipatgandakan pengembalian atas ekuitas juga kecil. Sudah tentu prospek tingkat pengembalian yang tinggi akan dikehendaki, namun para investor tidak ingin menghadapi resiko. Karena itu, perusahaan perlu mencari keseimbangan antara tingkat pengembalian dengan tingkat resiko.

\section{METODOLOGI PENELITIAN}

Penelitian ini pada merupakan penelitian kuantitatif, yaitu menjelaskan hubungan antara variable dengan menganalisis data numeric (angka) menggunakan metode statistik melalui pengujian hipotesis secara asosiasi. Penelitian ini menggunakan dimensi waktu secara times series. Penelitian juga ini menggunakan lingkungan riil dimana unit analisisnya menggunakan industry asuransi yang ada di Indonesia. Sumber data penelitian ini berasal dari data sekunder yang diambil dalam laporan keuangan perusahaan asuransi yang dapat diunduh pada website perusahaan.

Jenis penelitian ini adalah penelitian kausal yang bertujuan untuk menjelaskan variabel-variabel yang diteliti serta pengaruhnya melalui pengujian hipotesis (Sugiyono, 2013). Hal ini sesuai dengan tujuan penelitian yaitu untuk menganalisis struktur modal, premi neto dan profitabilitas terhadap solvabilitas perusaaan asuransi di indonesia. Pendekatan penelitian yang digunakan adalah pendekatan penelitian kuantitatif karena menekankan pada pengujian teori-teori melalui pengukuran variabel-variabel penelitian secara angka dan melakukan analisis data dengan prosedur statistik. Populasi dalam penelitian ini adalah perusahaan asuransi jiwasraya yang terdaftar di Bursa Efek Indonesia (BEI) yang mempublikasikan laporan keuangan dan annual reportnya.

Data yang telah dikumpulkan ditabulasikan untuk diproses dalam olah data dengan eviews. Metode analisis untuk uji hipotesis digunakan analisis regresi berganda model data panel. Sebelum uji regresi dilakukan analisis statistik deskriptif. Statistik desktriptif dilakukan untuk mendapatkan 
gambaran variabel penelitian yang mencakup nilai minimum, nilai maksimum, mean, dan standar deviasi. Untuk variabel dummy dilakukan analisis deskriptif frekuensi. Dalam analisis regresi juga sekaligus dilakukan uji hipotesis (uji $t$, uji koefisen determinan dan uji $f$ ).

\section{HASIL DAN PEMBAHASAN}

Penelitian ini memiliki tiga hipotesis yaitu pengujian langsung yaitu pengaruh struktur modal terhadap tingkat solvabilitas, pengaruh premi neto terhadap tingkat solvabilitas, dan pengaruh profitabilitas terhadap solvabilitas. Penelitian ini juga menggunakan lima variable kontrol yang terdiri dari ukuran perusahaan, umur perusahaan, inflasi, interest rate, dan rasio BOPO.

1) Struktur Modal Berpengaruh Negatif Terhadap Solvabilitas

Berdasarkan hasil analisa bahwa struktur modal memiliki pengaruh negatif terhadap solvabilitas (RBC) sebagaimana yang ditunjukan pada tabel 4.5. Dengan demikian cukup bukti secara empiris bahwa struktur modal memiliki pengaruh negatif terhadap solvabilitas (RBC). Hasil ini menunjukan bahwa rasio struktur modal perusahaan asuransi yang berasal dari hutang jangka panjang berpengaruh terhadap solvabilitas perusahaan dalam hal ini berdampak pada rasio RBC. Hal ini sesuai dengan hipotesis peneliti dimana struktur modal berpengaruh negatif terhadap solvabilitas (RBC) artinya hipotesis peneliti diterima.

Penjelasan perhitungan diatas menghitung asset dikurangi dengan hutang kemudian dikurangi dengan jumlah resiko yang telah di hitung, sehingga dalam hal ini struktur modal yang di diproxikan sebagai rasio hutang jangka panjang dibagi dengan aset perusahaan, memiliki dampak yang sangat signifikan dalam mempengaruhi rasio solvabilitas (RBC). Rasio struktur modal yang tinggi sudah pasti hutang juga semakin tinggi dan berdampak langsung terhadap solvabilitas (RBC) perusahaan asuransi, sehingga manajemen harus menjaga tingkat hutang perusahaan terutama terkait atas hutang jangka panjang. 
Peneliti juga menganalisa dimana teori signaling juga terjadi dalam peneltian ini Teori ini didasarkan pada premis bahwa manajer dan pemegang saham tidak mempunyai akses informasi perusahaan yang sama. Ada informasi tertentu yang diketahui oleh manajer, sedangkan pemegang saham tidak tahu informasi tersebut. Stephen A. Ross pada tahun 1977 dalam Bell Journal of Economics vol. 8 dengan judul The Determinans of Financial Structure : The Incentive Signaling Approach, menyatakan bahwa ketika perusahaan menerbitkan hutang baru, menjadi tanda atau sinyal bagi pemegang saham atau investor potensial tentang prospek perusahaan di masa mendatang mengalamai peningkatan. Dasar pertimbangannya adalah penambahan hutang berarti keterbatasan arus kas dan biaya - biaya beban keuangan juga meningkat, dan manajer hanya akan menerbitkan hutang baru yang lebih banyak bila mereka yakin perusahaan kelak dapat memenuhi kewajibannya. Atas dasar hal tersebut maka rasio struktur modal yang tinggi akan menjadi tanda bagi pemegang saham juga bahwa tentang prospek perusahaan dimasa mendatang akan mengalami peningkatan, sedangkan bagi managemen dengan kenaikan rasio struktur modal dapat berarti perusahaan butuh dana segar guna memenuhi operasional perusahaan.

Hasil penelitian ini sejalan dengan penelitian yang dilakukan oleh (Fernandes Moniaga, 2013) yang menyatakan bahwa profitablitas memiliki pengaruh negative terhadap solvabilitas. Namun memiliki perbedaan dengan penelitian yang dilakukan oleh (Utama, 2017).

Hasil analisa yang dilakukan peneliti terhadap pengaruh struktur modal terhadap solvabilitas juga sejalan dengan penelitian terdahulu yang dilakukan oleh Prof Nikhil Bhusan pada tahun 2015 dimana saat itu penelitian berfokus pada asuransi jiwa di India, penelitian itu menghasilkan kesimpulan posisi hutang jangka panjang memiliki resiko yang tinggi dikarenakan waktu yang cukup lama sehingga kecenderungan beresiko tinggi kedepannya jika resiko tidak dapat di kontrol terhadap solvabilitas sehingga dapat mengalami gagal bayar. Perlu menjadi pertimbangan juga tentang faktor resiko dalam 
mengambil keputusan atas hutang jangka panjang. Kemudian penelitian yang dilakukan oleh Penelitian yang dilakukan oleh (Tanjung, 2015) bahwa penurunan rasio struktur modal akan meningkatkan rasio solvabilitas jika penggunaan hutang jangka panjang yang lebih besar dibandingkan peningkatan penggunaan modal sendiri maka rasio solvabilitas akan lebih rendah. Peningkatan rasio struktur modal yang disebabkan oleh peningkatan penggunaan hutang jangka panjang yang di barengi dengan peningkatan penggunaan modal sendiri akan menurunkan rasio solvabilitas bank.

2) Premi Neto Tidak Berpengaruh Terhadap Solvabilitas

Hasil analisa penelitian menunjukan bahwa tidak terdapat pengaruh premi neto terhadap tingkat solvabilitas pada perudahaan asuransi seperti yang disajikan pada tabel 4.5 dimana probilitas 0,438 > 0,05 dan koefisien 9,712. Hal ini menunjukan jika premi neto naik sebesar 1 satuan, maka RBC naik sebesar 9.712918 dengan asumsi ceteris paribus. Dengan demikian maka hipotesis penelitian ini diterima karena sesuai dengan hasil penelitian.

Hipotesis ini juga sama dengan penelitian terdahulu yang dilakukan oleh Kirmizi dan Bashir Ahmad Joo yang menyatakan tidak terdapat pengaruh premi neto terhadap RBC. Secara teoritis premi neto merupakan tahapan awal dalam memperoleh laba yang besar, laba yang besar akan berpengaruh terhadap neraca perusahaan, namun demikian harus juga di dukung dengan beban yang efisien dan juga didukung dengan analisa underwriting yang efektif. karena rasio underwriting dalam penelitian Georgious pitselis berpengaruh positif terhadap solvabilitas.

Premi neto tidak berpengaruh terhadap solvabilitas hal ini dikarenakan pada perhitungan rasio solvabiilitas (RBC) premi neto tidak dapat secara langsung berdampak pada aset perusahaan dimana aset perusahaan merupakan unsur yang sangat mempengaruh rasio RBC. Premi neto yang besar juga akan memungkinkan menghasilkan laba bersih yang besar, yang nantinya akan berdampak pada neraca perusahaan. 
Perusahaan asuransi selalu terkait dengan teori pengalihan resiko (Risk Transver Theory) sehingga analisa underwriting menjadi hal yang sangat penting, jangan sampai perusahaan membebankan premi kepada nasabah untuk sesuatu pertanggungan yang nilai resiko lebih besar dari yang dibayarkan sehingga perusahaan akan dapat mengalami kerugian yang berdampak secara langsung pada neraca perusahaan. Kerugian yang timbul tersebut juga akan mempengaruhi portpolio investasi perusahaan. Namun hasil penelitian ini bertolak belakang dengan hasil penelitian yang dilakukan oleh (Hidayat, 2021) dan (Sastri, 2017) yang menyatakan bahwa premi berpengaruh terhadap tingkat solvabilitas.

3) Profitabilitas Berpengaruh Negatif Terhadap Solvabilitas

Dari hasil analisa penelitian didapatkan hasil bahwa tidak terdapat pengaruh profitabilitas dalam hal ini diukur dengan ROA terhadap solvabilitas dalam hal ini diukur dengan risk based capital (RBC), dimana tercermin dari hasil peneliti probabilitas $0.59>0.05$, sedangkan hipotesis peneliti adalah terdapat pengaruh negatif profitabilitas terhadap solvabilitas. Hipotesis peneliti kali ini artinya ditolak.

Peneliti melakukan analisa atas hasil penelitian bahwa tidak terdapat pengaruh profitabilitas (ROA) terhadap solvabilitas (RBC), hal ini dikarenakan pertama pada perhitungan rasio solvabilitas dengan menggunakan risk based capital pada industri asuransi tidak berhubungan secara langsung terhadap perhitungan kenaikan atau penurunan profitabilitas yang diukur dengan (ROA) memang akan berdampak pada neraca perusahaan namun perhitungan risk based capital menghitung dari posisi aset yang diperkenankan terhadap hutang perusahaan yang kita sebut sebagai tingkat solvabilitas, tingkat solvabilitas ini akan di bagi dengan batas tingkat solvabilitas minimal dimana merupakan ukuran resiko yang diestimasi akan di terima perusahaan. Kedua itu mengindikasikan bahwa penggunaan modal sendiri (dampak dari kenaikan profitabilitas ke ekuitas perusahaan) pada industri asuransi untuk meningkatkan aset perusahaan terlihat bahwa perusahaan asuransi dalam 
meningkatkan aset perusahaan lebih menggunakan hutang perusahaan sehingga tidak berpengaruh terhadap profitabilitas. Hal ini sesuai dengan hipotesis pertama.

Batas tingkat solvabilitas minimum menghitung resiko kegagalan pengelolaan aset, resiko ketidakseimbangan antara nilai kekayaan dan kewajiban dalam setiap jenis mata uang asing ketidakseimbangan antara nilai aset dan liabilitas dalam setiap jenis mata uang asing, resiko perbedaan antara beban klaim yang terjadi dan beban klaim yang diperkirakan, resiko ketidakcukupan premi akibat perbedaan hasil investasi yang diasumsikan dalam penetapan premi dengan hasil investasi yang diperoleh, resiko reasuransi, resiko kegagalan dalam proses produksi, ketidakmampuan sumber daya manusia atau sistem untuk berkinerja baik, atau adanya kejadian lain yang merugikan, resiko kegagalan dalam proses produksi, ketidakmampuan sumber daya manusia atau sistem untuk berkinerja baik, atau adanya kejadian lain yang merugikan berkaitan dengan pengelolaan dana investasi, sehingga perhitungan dalam risk based capital sangat komprehensif dan detail.

Dalam hipotesis penelitian ini peneliti terdahulu menggunakan ukuran solvabilitas yang berbeda serta indurstri yang berbeda dengan penelitian ini, sehingga peneliti dalam menarik kesimpulan hipotesis mengaju pada referensi penelitian terdahulu. Hasil dari penelitian ini sejalan dengan jurnal yang dikeluarkan oleh Reni Marlina dengan judul The Influence of Risk Based Capital to Profitability in Jasindo Company, dimana dalam penelitiannya ukuran yang digunakan serta industri yang diteliti telah sesuai dengan tesis ini. Hasil dari penelitiannya menunjukan bahwa tidak terdapat pengaruh antara risk based capital dengan profitabilitas terutama ROA dan ROE, hal ini dikarenakan dalam menghitung RBC memperhitungkan batas tingkat solvabilitas dimana dalam penelitiannya kenaikan tingkat solvabilitas akan diikuti dengan kenaikan batas tingkat solvabilitas yang menghasilkan RBC yang sejalan juga namun tidak demikian dengan profitabiltas yang justru mengalami kenaikan dan penurunan pada periode penelitian yang dilakukan, penelitiannya 
menunjukan bahwa profitabilitas bukan faktor untuk mempengaruhi rasio solvabilias (RBC), terdapat faktor lain yang memiliki pengaruh terhadap risk based capital. Hasil penelitian ini sejalan dengan penelitian yang dilakukan oleh (Daniel, 2020) dan (Mahfud, 2015). Namun, hasil penelitian ini bertolak belakang dengan penelitian yang dilakukan oleh (Hasib, 2018), (Agus, 2011), (Supriyono, 2019) dan (Nursalamah, 2021) yang menyatakan bahwa profitabilitas berpengaruh secara simultan terhadap solvabilitas.

\section{KESIMPULAN}

Berdasarkan hasil penelitian yang telah dilakukan tentang pengaruh struktur modal, premi neto dan profitability terhadap solvabilitas (Risk Based Capital) perusahaan asuransi di Indonesia:

Struktur modal berpengaruh negatif terhadap solvabilitas (RBC). Hal ini didasarkan pada besarnya nilai probabilitas 0,0008 $<0,05$, Secara teori hal ini dikarenakan penggunaan hutang jangka panjang memiliki resiko yang tinggi dikarenakan waktu yang cukup lama sehingga kecenderungan gagal bayar kedepannya juga semakin besar, sehingga akan menurunkan rasio solvabilitas perusahaan (RBC).

Premi neto tidak memiliki pengaruh terhadap solvabilitas (RBC). Hal ini terbukti dari pengujian statistik dimana besarnya probabilitas 0,4385 > 0,05.Secara teori premi neto merupakan indikator awal dalam memperoleh laba perusahaan nemun demikian tidak memiliki dampak yang dapat mempengaruhi aset yang diperkenankan dan hutang perusahaan dalam hal ini neraca, perhitungan RBC sendiri meliputi faktor yang ada di neraca perusahaan, sehingga dalam menghitung RBC tidak memiliki pengaruh.

Profitabilitas tidak memiliki pengaruh terhadap solvabilitas (RBC), Hal ini terbukti dari hasil statistik besar nilai probabilitas 0,591>0,05. Profitabilitas sebagai penambah modal perusahaan tidak digunakan untuk meningkatkan aset perusahaan. RBC dihitung dari posisi aset yang diperkenankan terhadap hutang perusahaan yang kita sebut sebagai tingkat solvabilitas, tingkat 
solvabilitas ini akan di bagi dengan batas tingkat solvabilitas minimal dimana merupakan ukuran resiko yang diestimasi akan di terima perusahaan. Sehingga profitabilitas secara perhitungan pun tidak memiliki dampak secara langsung yang terkait dengan perhitungan RBC.

\section{IMPLIKASI PENELITIAN}

Implikasi penelitian ini diharapkan agar bisa menambah khasanah ilmu pengetahuan berkaitan dengan pengaruh struktur modal, premi netto dan profitabilitas berpengaruh positif signifikan terhadap solvabilitas perusahaan asuransi di Indonesia.

\section{REFERENSI}

Agnes Sawir. (2005). Analisis Kinerja Keuangan dan Perencanaan Keuangan Perusahaan. Jakarta : PT Gramedia Pustaka:

Agnes Sawir. (2009). Analisa Kinerja Keuangan dan Perencanaan keauangan. Perusahaan. Jakarta : PT. Gramedia Pustaka Utama

Agus, S. S. (2011). Pengaruh pertumbuhan modal dan aset terhadap Rasio Risk Based Capital (RBC), pertumbuhan premi neto dan profitabilitas perusahaan asuransi umum di Indonesia. PEKBIS (Jurnal Pendidikan Ekonomi Dan Bisnis), 3(01).

Agus Sartono. (2010). Manajemen Keuangan Teori dan Aplikasi (4th ed.), Yogyakarta: BPFE.

Amrita Maulidia Rahmah. (2016). Pengaruh Likuiditas, Solvabilitas dan Aktivitas terhadap Profitabilitas pada Perusahaan Otomotif yang terdaftar di Bursa Efek Indonesia Periode 2012-2014. Bisma Universitas Pendidikan Ganesha Jurusan Manajemen (Volume 4): Indonesia Singaraja.

Bringham, Houston. (2010). Dasar-Dasar Manajemen Keuangan Buku I Edisi 11, Jakarta : Salemba Empat.

Bashir Ahmad Joo. (2013). Analysis of Financial Stability of IndiaNon life Insurance Companies. Asian Journal of Finance \& Accounting, Vol. 5, No. 1. 
University of Kashmir, Srinagar

Brealey, Richard A., Stewart C. Myers dan Alan J. Marcus.(2008). Dasar-Dasar Manajemen Keuangan Perusahaan, Jilid Kedua, Edisi Kelima: Jakarta. Erlangga.

Cekrezi, Anila. (2013). The Determinants of Capital Structure: Evidence from Albania.Vol 2 No.9, Albania : University Elbasana

Daniel, E. S. dan S. M. E. (2020). Pengaruh Profitabilitas, Ukuran Perusahaan dan Reasuransi Terhadap Solvabilitas Perusahan Asuransi Jiwa Unik LINK di Indonesia. 274-282.

Daiva Jureviciene. (2016). Indirect Factors Affecting Personal Solvency Empirical Analysis of Lithuania Consumer Credit Market. European Scientific Journal January 2016 edition vol.12, No.1:Lithuania.Technical University.

Dendawijaya, Lukman. (2005). Manajemen Perbankan, Edisi Kedua, Cetakan Kedua: Jakarta. Ghalia Indonesia.

De Haan L \& Kakes. (2010). Are Not Risk Based Capital Requirements for Insurance Company Binding?:Journal of Insurance Issue.Amsterdam.

Dewi Yanti, P. S. M., \& Wirama, D. G. (2017). Pecking Order Theory: Pengaruh Profitabilitas Dan Pertumbuhan Perusahaan Pada Keputusan Pendanaan Perusahaan. E-Jurnal Akuntansi, 18(3), 2423-2450.

Fernandes Moniaga. (2013). Struktur Modal, Profitabilitas Dan Struktur Biaya Terhadap Nilai Perusahaan Industri Keramik, Porcelen Dan Kaca Periode 2007 - 2011. Jurnal EMBA, Vol.1 No 4(4), Hal. 433-442.

Ferry, M.G., dan Jones, W.H. (1979). Determinants of financial structure: A new methodological approach. Journal of Finance, 01 XXXXIV(3).

Ghozali. (2011). Structural Equation Modeling Metode Alternatif Dengan Partial Least Square PLS Edisi 3. Semarang:Badan Penerbit UNDIP Harjito, D. A. (2011). Teori Pecking Order dan Trade-Off dalam analisis struktur modal di Bursa Efek Indonesia. Jurnal Siasat Bisnis, 15(2), 187-196.

Hasib, S. A. dan F. F. (2018). Pengaruh Ukuran Perusahaan, Hasil Investasi, Dan 
Profitabilitas Terhadap Solvabilitas Asuransi Syariah Di Indonesia Periode 2012-2016. Jurnal Ekonomi Dan Bisnis Islam (Journal of Islamic Economics and Business), 4(2), 91. https:/ / doi.org/10.20473/jebis.v4i2.9807

Harahap, Sofyan Syafri. (2009). "Analisis Kritis Atas Laporan Keuangan". Jakarta: RajaGrafindo Persada

Henryk Gurgul. (2014). The Impact of Alteration in The Local Insolvency Legislation on Business Bankruptcy Rates in Poland. Statistics in Transition new series, Summer 2014 Vol. 15, No. 3, pp. 453-466.Poland

Hidayat, N. I. A., Susanti, S., \& Zulaihati, S. (2021). Pengaruh Premi, Hasil Investasi dan Risk Based Capital terhadap Laba Perusahaan Asuransi Syariah Indonesia 2019. Jurnal Akuntansi, Keuangan, Dan Manajemen, 2(4), 327-344. https://doi.org/10.35912/jakman.v2i4.552

Hilmi, Utari dan Syaiful Ali. (2008). Analisis Faktor-Faktor yang Mempengaruhi Ketepatan Waktu Penyampaian Laporan Keuangan (Studi Empiris pada Perusahaan-Perusahaan yang terdaftar di BEJ Periode 20042006). Simposium Nasional Akuntansi11

Husnan, Suad dan Enny Pudjiastuti. (2002). Dasar - Dasar Manajemen Keuangan.Yogyakarta: Unit Penerbitan dan Percetakan Akademi Manajemen Perusahaan YKPN.

Jiang Chen. (2012). The Impact of Risk Based Capital Requirments in PropertyLiability Insurance. Journal International Insurance and Risk Management July 18-21, 2012 Qingdao China

Kasmir. (2012). Analisis Laporan Keuangan, Jakarta: PT.Raja Grafindo Persada Kirmizi Susi Surya Agus. (2011). Pengaruh Pertumbuhan Modal dan Aset Terhadap Rasio Risk Based Capital (RBC), Pertumbuhan Premi Neto dan Profitabilitas Perusahaan Asuransi. Pekbis Jurnal, Vol.3, No.1. Universitas Riau

Komalasari, P. T. (1999). Model Perencanaan Sistem Informasi: Suatu Perspektif Teori Agensi. Jurnal Akuntansi \& Auditing Indonesia, 3(2), 161-175.

Ludovicus,Sensi. 2006. Memahami Akuntansi Asuransi Kerugian (Accounting For 
General Insurance).Jakarta : PT.Prima Mitra Edukarya

Mahfud, A. P. K. T. dan M. K. (2015). Analisis Pengaruh Kemampuan Membayar Klaim, Profitabilitas, Risiko Underwriting, Dan Reasuransi Terhadap Solvabilitas Perusahaan Asuransi). Diponegoro Journal of Management, 4(3), 1-13. http:/ / ejournal-s1.undip.ac.id/index.php/dbr

Mullins, J., Walker, O.C., Boyd, H.W. and Larreche, J.C. (2005). Marketing Management : A Strategic Decision - Making Approach. McGraw - Hill, New York.

Mulyadi. (2013). Sistem Akuntansi. Jakarta: Salemba Empat.

Mirie Mwangi. (2015). The Determinants of Financial Performance in General Insurance Company in Kenya. European Scientific Journal January 2015 edition vol.11, University of Nairobi, School of Business, Kenya

Nelyumna, N. (2018). Faktor-Faktor Yang Mempengaruhi Struktur Modal Pada Perusahaan Manufaktur Yang Go Public. Liquidity, 5(1), 19-26. https:// doi.org/10.32546/lq.v5i1.61

Nasrullahi M Tanjung. (2015). Analisis of Capital Structure Toward Banks Solvency On The BUMN Bank in Indonesia. Jurnal EMBA 207 Vol.3 No.4, Hal. 207-214. Universitas Sam Ratulangi Manado

Niresh, J. Aloy dan T. Velnampy. (2014). “Firm Size and Profitability: A Study of Listed Manufacturing Firms in Sri Lanka", International Journal of Business and Management, Volume 8 hal 57-64.Srilangka.

Nikhil Bhusan. (2015). Capital Structure of Life Insurance Companies in India (an analytical study). Jounal International Economic and Business Review.University Silchar India

Nursalamah, L., Zulpahmi, Z., \& Ridwan Zamzany, F. (2021). Tingkat Premi, Klaim dan Risk Based Capital (RBC) Berpengaruh Terhadap Profitabilitas Perusahaan Asuransi Syariah. Al-Urban: Jurnal Ekonomi Syariah Dan $\begin{array}{lll}\text { Filantropi Islam, } & 5(1), & \text { 1-9. }\end{array}$ https://doi.org/10.22236/alurban_vol4/is1pp101-114

Okky Pauli. (2015). Determinants of Islamic Banks Profitability in Indonesia. 
Journal of Business and Management Vol. 4, No.1, 2015: 175-185. Institut Teknologi Bandung, Indonesia

Oner, Kaya. (2015). The Effects of Firm-Specific Factors on the Profitability of Non-Life Insurance Companies in Turkey. Journal International Financial. Gazi University, Turkey.

Oktaviani, P. H. dan R. M. (2012). Determinan kebijakan hutang (dalam agency theory dan pecking order theory). Dinamika Akuntansi, Keuangan Dan Perbankan Universitas Stikubank, 1(1), 11-24.

Oktavina, M., \& Manalu, S. (2018). Pecking Order and Trade-off Theory in Capital Structure Analysis of Family Firms in Indonesia. Jurnal Keuangan Dan Perbankan, 22(1), 73-82. https:/ / doi.org/10.26905/jkdp.v22i1.1793

Peraturan Menteri Keuangan No.53/PMK.10/2012

Peraturan Pemerintah (PP) Nomor 63 Tahun 2004

Peraturan Ketua Badan Pengawas Pasar Modal dan Lembaga Keuangan Nomor PER-08/BL/2012

Peraturan Ketua Badan Pengawas Pasar Modal dan Lembaga Keuangan Nomor : PER-09/Bl/2011

Pratama Rahardja dan Mandala Manurung. (2008). Teori Ekonomi Makro: Suatu Pengantar, Lembaga Penerbit FE UI.

Reni Marlina .(2013). The Influence of Risk Based Capital to Profitability in Jasindo Insurance Company. South East Asia Journal of Contemporary Business, Economics and Law, Vol. 2, Issue 1 (June). STIE EKUITAS Bandung Indonesia

Riswan dan Nina Permata Sari. 2015, Factors Affecting Capital Structure in Manufacturing Companies Go Public in Indonesia Stock Exchange in The Year 2011-2013. Jurnal Akuntansi dan Keuangan. 6 (2) : 177-201.

Riyanto,Bambang. (2011). Dasar-Dasar Pembelanjaan Perusahaan. Yogyakarta : BPFE

Simanjuntak, Binsar. H. dan Lusy Widiastuti. (2004). Faktor-Faktor Yang Mempengaruhi Kelengkapan Pengungkapan Laporan Keuangan Pada 
Perusahaan Manufaktur Yang Terdaftar Di Bursa Efek Jakarta. Jurnal Riset Akuntansi Indonesia. Vol 7. No. 3. pp 351-366.

Sastri, I. A. I. P., Edy Sujana, S. E., \& Sinarwati, N. K. (2017). Pengaruh Pendapatan Premi, Hasil Underwriting, Hasil Investasi Dan Risk Based Capital Terhadap Laba Perusahaan Asuransi (Studi Empiris pada Perusahan Asuransi yang Terdaftar di Bursa Efek Indonesia periode 20112015). JIMAT (Jurnal Ilmiah Mahasiswa Akuntansi) Undiksha, 7(1).

Samuelson, Paul A. dan William D. Nordhaus. (2004). Ilmu Makroekonomi. Edisi Ketujuhbelas. Jakarta: PT. Media Global Edukasi

Sutrisno. (2007). Manajemen Keuangan, Ekonesia. Yogyakarta : BPFE

Supriyono, A. E. (2019). Pengaruh Risk Based Terhadap Profitabilitas Pada

Perusahaan Asuransi Syariah. Jurnal Aktiva : Riset Akuntansi Dan Keuangan, 1(1), 26-37. https:// doi.org/10.52005/aktiva.v1i1.17

Tamalonggehe, S., Rindengan, A. J., \& Manurung, T. (2017). Perhitungan Premi Netto Tahunan Dalam Menganalisis Komponen Biaya Pada Perusahaan Asuransi Jiwa Bumiputera Annual Net Premium Estimation In Analyse Of Cost Components on Bumiputra Life Insurance Company. E-Jurnal Unstrat, $6(2), 63-72$.

Tanjung, N. (2015). Analisis Penggunaan Struktur Modal Dalam Kaitan Solvabilitas Perbankan Pada Bank Bumn Di Indonesia. Jurnal Riset Ekonomi, Manajemen, Bisnis Dan Akuntansi, 3(4), 207-214.

Utama, I. P. D. dan A. . G. S. (2017). Pengaruh pertumbuhan perusahaan, struktur modal, dan profitabilitas terhadap nilai perusahaan. Riset Akuntansi Dan Bisnis Airlangga, 2(1), 135-148.

Van Horne, James C. (2007). Fundamental of Financial Managemen, Prinsip Prinsip Managemen Keuangan, Jakarta : Salemba Empat.

Veithzal Rivai. (2007). Bank and Financial Institute Management. Jakarta: PT. Raja GrafindoPersada

Warsono. (2003). Manajemen Keuangan Buku I. Edisi Ketiga. Malang: Bayumedia 
Waqas bin Khidmat. (2015). Impact of Liquidity and Solvency on Profitability Chemical Sector of Pakistan. EMI, Vol. 6, Issue 3. GC University, Faisalabad, Pakistan

Wild, John, \& K. R. Subramanyam. (2009). Financial Statement Analysis, McGraw-Hill International Edition.

Winarno, Wing Wahyu. (2009). Analisis ekonometrika dan statistika dengan eviews. Edisi kedua. UPP STIM YKPN. Yogyakarta

Wikartika, I., \& Fitriyah, Z. (2018). Pengujian Trade Off Theory dan Pecking Order Theory di Jakarta Islamic Index. BISMA (Bisnis Dan Manajemen), 10(2), 90. https:/ / doi.org/10.26740/bisma.v10n2.p90-101

Yin Yuxuan. (2014). An empirical study on factors influencing capital structure of pharmaceutical listed corporations. Journal of Chemical and Pharmaceutical Research, 2014, 6(6):1042-1046 Honoi University China.

Yularto, A. Dan A. Chariri. (2009). Analisis Perbandingan Luas Pengungkapan Sukarela dalam Laporan Tahunan Perusahaan yang Terdaftar di Bursa Efek Jakarta Sebelum Krisis dan Pada Periode Krisis," Jurnal Maksi vol. 2, Januari pp.35-51. 